\title{
Chineseness and Chinese Indonesian Business Practices: A Generational and Discursive Enquiry
}

\author{
Juliette Koning
}

Received: 2 September 2006 / Accepted: 19 April 2007 /

Published online: 7 July 2007

(C) Springer Science + Business Media B.V. 2007

\begin{abstract}
This paper discusses the role and meaning of Chineseness in business conduct among different generations of Chinese Indonesian entrepreneurs active in small and medium sized enterprises. This issue is raised in order to inspire the ongoing debate concerning the characteristics of ethnic Chinese business practices in Southeast Asia, and to offer a way out of the culturalist - criticalist impasse by addressing topics that are often neglected: the voice of those concerned, the business practices of Chinese Indonesian entrepreneurs in the SME sector, and generational differences.
\end{abstract}

Keywords Chinese Indonesian entrepreneurs · Chineseness · Ethnic identity · Generations · Nation state $\cdot$ Yogyakarta

\section{Introduction}

Over the last few decades the entrepreneurial activities of the ethnic Chinese diaspora in Southeast Asia have received ample attention in academic debates. This scholarly attention is related to an impressive business presence of ethnic Chinese companies in the region, which asked for explanations. A large body of literature has emerged arguing that because of specific cultural traits (personal networks, ethnic affinity, Confucian work ethics) ethnic Chinese businesses function successfully in the new home countries and in business contacts across borders. ${ }^{1}$ This culturalist approach from which the phrases 'Chinese network capitalism' and 'bamboo

\footnotetext{
${ }^{1}$ Important works in this tradition are: Gordon Redding, The Spirit of Chinese Capitalism (Berlin, New York: Walter de Gruyter, 1990); Joel Kotkin, Tribes: How Race, Religion, and Identity Determine Success in the New Global Economy (New York: Random House, 1993); Murray Weidenbaum and Samuel Hughes, The Bamboo Network: How Expatriate Chinese Entrepreneurs Are Creating a New Economic Superpower in Asia (New York: The Free Press, 1996).
}

J. Koning $(\bowtie)$

Department of Culture, Organization and Management, VU University Amsterdam,

Amsterdam, The Netherlands

e-mail: JBM.Koning@fsw.vu.nl 
network' evolved, is currently being questioned. Attempts are made to deessentialize or demystify this so-called culturalist approach to Chinese business conduct. ${ }^{2}$ These studies argue that too much emphasis has been placed on the role of a common ethnic identity as the main factor stimulating business success and business ties both nationally and internationally. This new avenue, hereafter referred to as 'criticalist', explores what is left of the assumption that 'the Chinese' conduct business (either nationally or transnationally) mainly based on intra-ethnic affiliations.

This paper departs from the position that the ongoing debate among the 'culturalists' and 'criticalists' as to the role of ethnicity in ethnic Chinese business conduct lacks three important dimensions that could be crucial in resolving some of the impasses in this debate. Firstly, and most importantly, the voice of those concerned. What do the ethnic Chinese businesspeople themselves have to say about their intra-ethnic and/or interethnic ties? How do they narrate about their business conduct and the role and meaning (if any) of being Chinese therein? Secondly, empirical data on Chinese Indonesian business practices in general and on small and medium sized enterprises in particular, are hard to find. ${ }^{3}$ The extensive literature on ethnic Chinese business conduct in Southeast Asia is rather quiet on the situation of ethnic Chinese entrepreneurs in Indonesia. ${ }^{4}$ Most attention has gone to the characteristics of a few large conglomerates that partnered up with former president Suharto. As a result little is known about the manner in which ethnicity does or does not play a key role in Chinese Indonesian small and medium sized enterprises. What can the Chinese Indonesian case reveal in relation to the ongoing debate in which they have been rather invisible? And thirdly, what about generational differences among ethnic Chinese entrepreneurs residing in Southeast Asia? Do younger and older generation entrepreneurs employ similar business strategies and similar networks? Is there a change in perceiving of ethnic ties? If so, what does this imply for our knowledge of Chinese business identities?

In line with the above, in this paper I will explore the role and meaning of Chineseness among different generations of Chinese Indonesian entrepreneurs with respect to their business conduct. I shall do so by elaborating on the discursive practices on 'being Chinese' in order to address the ideological, institutional and political dimensions involved in this question; dimensions that are often neglected while studying ethnic Chinese business practices as such. The discursive approach tries to incorporate the position that ethnicity is not "primordial, essential, and unchanging", but rather situational; but also that ethnicity as a collective identity can be "an important and early dimension of self-identification". The active role of the

\footnotetext{
${ }^{2}$ See for instance: Terence Gomez and Michael Hsiao, eds., Chinese Business in Southeast Asia. Contesting Cultural Explanations, Researching Entrepreneurship (London, New York: RoutledgeCurzon, 2004); Michael Jacobson, ed., "De-Essentialising 'Chinese Capitalism' in Southeast Asia," NIASnytt 3 (2004); Thomas Menkhoff and Solvay Gerke, eds., Chinese Entrepreneurship and Asian Business Networks (London, New York: Routledge, 2004).

${ }^{3}$ Whereas relating to my research data I shall use the term Chinese Indonesians, the academic literature more often uses the term ethnic Chinese, especially in the Southeast Asian context.

${ }^{4}$ The restricted knowledge, compared for instance with research on ethnic Chinese businesses in Malaysia and Singapore, is related to the fact that studying the ethnic Chinese was rather difficult during the New Order regime (1965-1998) as both official permission to do so would be difficult to obtain and at the same time Chinese Indonesians were not eager to stand in the spotlights.

${ }^{5}$ Richard Jenkins, Social Identity (London: Routledge, 2004), 65.

글 Springer
} 
Indonesian nation state in manipulating ethnic identity might have instigated the latter, both among the Chinese and among the non-Chinese. In order to "go beyond the simple question of whether Chineseness as some sort of 'thing' frozen in time and space has survived or disappeared", a view is needed that takes into account different discursive practices. ${ }^{6}$

A noteworthy study in that perspective is an ethnographic study on ethnic Chinese traders in Sarawak (Malaysia). ${ }^{7}$ Yao carefully examines the essentialist demeanor of Chinese or Confucian Capitalism not by taking an anti-essentialist position in advance but by presenting the discursive performances of the group under study, taking due notice of "local desires and national agendas". 8 The end result falls somewhere in between "social imagination" and "actual experiences". 9 It is this kind of analysis that is pursued in this paper. Therefore, this paper intends to let the results speak for themselves and not to take a stance beforehand in either the 'cultural' or 'critical' camp.

In order to do justice to the situational dimension of identity and 'national agendas', it is imperative to include the particulars of the Indonesian context. The New Order regime (1965-1998) of former president Suharto with its fierce assimilation policy towards the ethnic Chinese has created a history of more than thirty years of suppressed ethnic identity. This is such a specific feature of the Indonesian case that it might reveal new insights for the debates on the role of ethnic identity in business conduct.

Research for this paper was conducted in 2004 in the city of Yogyakarta, central Java. ${ }^{10}$ The timeframe in which this study took place is quite relevant for the results. The interviews took place in the autumn of 2004, during the election of Susilo Bambang Yudhoyono as President, and room for ethnic Chinese expression was only

\footnotetext{
${ }^{6}$ Ariel Heryanto, "Ethnic Identities and Erasure; Chinese Indonesians in Public Culture," in Joel Kahn, ed., Southeast Asian Identities. Culture and the Politics of Representation in Indonesia, Malaysia, Singapore, and Thailand (London: I.B.Tauris Publishers, 1998), 110.

${ }^{7}$ Souchou Yao, Confucian Capitalism: Discourse, Practice and the Myth of Chinese Enterprise (London: RoutledgeCurzon, 2002).

${ }^{8}$ Ibid., 19.

9 Ibid., 39.
}

${ }^{10}$ The data collection is part of the author's research programme within the department Culture, Organisation and Management; VU University Amsterdam. The research programme studies the relationship between religious, ethnic and business networks among ethnic Chinese entrepreneurs in the SME sectors in various Southeast Asian countries. The interviewees in the Indonesian case were approached based on their membership of certain Christian movements in the city of Yogyakarta, on their being ethnic Chinese, belonging to different generations and being owner-manager of a small or medium sized enterprise. As such the sampling was within and across cases, a method that "puts flesh on the bones of general constructs and their relationships". See: Matthew Miles and Michael Huberman, Qualitative Data Analysis. An Expanded Source Book [second edition] (London: Sage Publications, 1994), 27. At the same time the sampling was purposeful with the aim to have information-rich cases. Fitting the interpretive approach here taken, the point of departure is more concerned with "description of persons, places and events ... the cornerstone of qualitative research" than with an attempt to generalize across time and space. See: Valerie Janesick, "The Dance of Qualitative Research Design: Metaphor, Methodolatry, and Meaning," in Norman Denzin and Yvonna Lincoln, eds., Strategies of Qualitative Inquiry (London: Sage Publications, 1998), 50. The data collection on several of the younger generation entrepreneurs was carried out by Arieke Oostra, student of the department, for her MA thesis. See: Arieke Oostra, Religie en Ondernemerschap. De etnische Chinezen in Indonesie [Religion and Entrepreneurship. The Ethnic Chinese in Indonesia] Unpublished MA thesis, (Amsterdam: VU University Amsterdam, 2005). 
just starting to open up. There was a lot of uncertainty among the Chinese Indonesian groups in Yogyakarta at that time as it was still unknown what the new, first directly chosen president and vice president (Jusuf Kalla) would signify for the Chinese Indonesian population.

Two groups of ethnic Chinese entrepreneurs were studied, older generation Chinese Indonesians (born in the 1940s-1950s) who often witnessed the severe curtailing of their Chineseness with the coming to power of the New Order regime in the mid1960 s, and a younger group born under the assimilation policy of the New Order (1960s-1970s). ${ }^{11}$ The choice to conduct the research in the city of Yogyakarta was a pragmatic one, as field sites often are. Being quite familiar with the city solved some of the access problems and as Yogyakarta has a large ethnic Chinese community, especially in the small and medium sized sectors, it was a good place to start. The semi-structured interviews were conducted as life and business histories of ownermanagers of small and medium sized enterprises with a focus on three major themes. First of all, personal issues: the role and meaning of Chineseness in personal and business life, educational backgrounds, and marriage patterns. Secondly, business conduct: enterprise and/or family business histories, business and management styles, decision-making processes on products, suppliers and partners. And thirdly, the role of networks: the interconnectedness of ethnic, religious and/or business ties.

The majority of those interviewed have a common descent from southern China (Fujian province) and are mostly second or third generation Chinese born in Indonesia. ${ }^{12}$ They all have a business that can be labelled small (less than 10 employees) or medium (between 10-100 employees) sized, for which start-up capital was most often derived from family resources (parents). ${ }^{13}$ In some cases the business is a continuation of a family business, in other cases the parents either sold their business and provided capital or they continued their business with the child setting up a related or different business. The older generation owner-managers of the medium sized firms are nearly all involved in side-businesses as well (in several cases export related); this was seldom the case among the small entrepreneurs and the younger ones. The majority of the small and medium enterprises in this study are in retail and services, with some manufacturing companies.

In the remainder of this paper, I shall discuss what Chineseness means in presentday Indonesia and in particular the manner in which the interviewees experience this after the fall of former president Suharto in 1998. This is followed by a brief discussion of ethnic Chinese identity and contested citizenship in Indonesia's recent history and the major issues of the 'Chinese capitalism' claim. After having outlined the major arguments I shall focus on what the interviewees consider 'Chinese values'

\footnotetext{
${ }^{11}$ See Appendix for details on the interviewees.

${ }^{12}$ First generation here means that the father of the interviewee was born in China and migrated to Indonesia, and that the interviewee was born in Indonesia (and hence first generation born in Indonesia); second generation here means that the grandfather on the father's side of the interviewee was born in China, hence the interviewee is second generation born in Indonesia, and so on. Most interviewees said to be Hokkien. Hokkien is a Chinese dialect of Fujian province in Southern China. There are large numbers of Hokkien descendants in Southeast Asia.

${ }^{13}$ For size of firm I follow ASEAN definitions where a small enterprise has less than 10 employees, a medium enterprise has between 10-100 employees and firms with more than 100 employees are considered to be large.
} 
in doing business. Next is a discussion of generational differences on being Chinese and doing business. The paper ends with concluding remarks.

\section{Chineseness Before, During and After Suharto}

Today is the time that the Chinese start to carry out their identity; with identity I mean intelligence, cultural values, that we are people who count, who matter. Yes it is time for the Chinese to show their identity, their social and cultural values. [Go] ${ }^{14}$

The discursive practices of the Chinese Indonesian entrepreneurs in this study only make sense, or at least can be better understood, in their proper context, which is their ethnic minority position, their often contested citizenship status (weak political position), and their dominant economic position. Combined, these positions impinge on identity questions (both in terms of self-representation and in terms of 'otherness'). The sketched picture of an ethnic minority that rules the Indonesian economy - the 5 per cent ethnic Chinese are said to control some 70-75 percent of medium and large scale private (non-state) enterprises ${ }^{15}-$ has resulted in a scapegoat position. ${ }^{16}$ Whatever 'crisis' the Indonesian nation state goes through, it is always the Chinese Indonesians who are blamed. The most recent example thereof took place in May 1998, at the height of the economic and political crisis, when in various cities on Java ethnic Chinese shops and houses were burned and women were raped. The events made world news and intensified the already incorporated feelings of insecurity among the Chinese Indonesians. ${ }^{17}$

\footnotetext{
${ }^{14}$ The names of the interviewees have been changed. If quotations end with [..] these are quotes from the interviews. The quotes have been translated from Indonesian into English by the author.

${ }^{15}$ Robert Hefner, "Introduction: Society and Morality in the New Asian Capitalisms," in Robert Hefner, ed., Market Cultures. Society and Morality in the New Asian Capitalisms (Boulder Colorado: Westview Press, 1998), 17.

${ }^{16}$ The Indonesian Population Census of 2000 mapped ethnic Chineseness for the first time since the colonial 1930-census. Ever since the 1930s the estimated number of ethnic Chinese was held to be somewhere around 5 to 6 million. The results of the 2000 census show that this number turned out to be much lower than taken for granted, namely some 3 million ethnic Chinese, which is about $1.5 \%$ of the total population. See: Leo Suryadinata, Evi Arifin and Aris Ananta, Indonesia's Population. Ethnicity and Religion in a Changing Political Landscape (Singapore: Institute of Southeast Asian Studies, Singapore, 2003), 101. The results of the 2000 census could be an under-representation as it was based on selfidentification meaning ethnic Chinese could choose to be stated ethnic Chinese or any other ethnicity. Seen against their insecure position in the Indonesian nation state it is assumed that many decided not to be 'mapped' as ethnic Chinese. Furthermore, the total number is based on only 11 of the 30 provinces in Indonesia. However, it could equally be possible that the lower number might be related to lower fertility rates among the ethnic Chinese, and to groups of ethnic Chinese leaving Indonesia as a result of the many violent attacks on them, the latest being the severe violent outbursts against Chinese property and people in May 1998. As a result there is no accurate or reliable number of the total ethnic Chinese population in Indonesia. See: ibid., 73-101.

${ }^{17}$ See for instance: Andreas Susanto, "Safety First: Strategies of Managing Insecurity among Chinese Indonesians in Yogyakarta," in Juliette Koning and Frans Husken, eds., Ropewalking and Safety Nets. Local Ways of Managing Insecurities in Indonesia (Boston, Leiden: Brill, 2006), 107-124; Emma Purdey, Anti-Chinese Violence in Indonesia, 1996-1999 (Singapore: Singapore University Press, 2006).
} 
Interpreting the discursive practices on Chineseness as "meanings and meaningmaking in a principled manner" is only possible "in the degree to which we are able to specify the structure and coherence of the larger contexts in which specific meanings are created and transmitted". ${ }^{18}$ In this paragraph I therefore explore these context settings, starting with the issue of identity, citizenship and ethnicity, followed in the next section by the economic situation.

The issue of ethnic Chinese identity is a recurring theme in academic writing on the ethnic Chinese in Indonesia. ${ }^{19}$ Especially interesting is the role of the state in "the selective creation and manipulation of ethnic identities" 20 in the process of nation building, which in Indonesia can be characterized as an ongoing attempt to forge a national identity out of a multi-ethnic populace. In such a frame of citizenship, the issue of identity relates to the question of how people see themselves as citizens (and hence their perceptions of rights and obligations), how they accordingly act upon such citizenship and their relation to the state and vice versa. ${ }^{21}$

This matter of citizenship and identity comes to its full meaning in the contention that the "alienness of Chinese can be understood as the ideological product of sociohistorical processes specific to Indonesia, particularly in its construction of nationhood". 22 One of the more important details from that history is the fact that the Dutch colonisers positioned the Chinese as intermediaries for European enterprises. $^{23}$ Next to being the largest group of immigrant Asians and the most economically powerful one, the Chinese were assigned shares in the lucrative opium trade by the colonizers at the expense of native entrepreneurs, and thus, the gap

\footnotetext{
18 Jerome Bruner, Acts of Meaning (Cambridge: Harvard University Press, 1990), 64.

${ }^{19}$ Discussions on the ethnic Chinese in Indonesia often start by explaining the difference between totok (China born Chinese, Chinese speaking and China-oriented) and peranakan (descendents of mixed marriages between totok men and indigenous-Indonesian women). Often this distinction is used to claim that the totok are more Chinese than the peranakan who are supposedly more assimilated (and have a longer history in Indonesia) and have lost their cultural roots, as it is also agued that the totok mostly live outside Java whereas the majority of the peranakan can be found on the island of Java. Some point out that this distinction is no longer relevant and that many peranakan regard Chinese culture and traditions as important, as is supposed for the totok. See: Yahya Wijaya, Business, Family and Religion. Public Theology in the Context of the Chinese-Indonesian Business Community (Bern: Peter Lang AG, 2002), 10-13. At one time in history though it was an important distinction, as Regulation 1946 allowed Chinese born in Indonesia to become Indonesian citizens. As local officials were rather inconsistent in carrying out this act, the act was clarified, allowing "peranakan Chinese to take Indonesian citizenship, but not the foreign-born, or totok, Chinese". See: Amy Freedman, Political Participation and Ethnic Minorities. Chinese Overseas in Malaysia, Indonesia and the United States (London, New York: Routledge, 2000), 101.

${ }^{20}$ Eugene Tan, "From Sojourners to Citizens: Managing the Ethnic Chinese Minority in Indonesia and Malaysia," Ethnic and Racial Studies 24:6 (2001), 952.

${ }^{21}$ Emma Jones and John Gaventa, "Concepts of Citizenship: a Review," IDS Development Bibliography 19 (Brighton, Sussex: Institute of Development Studies, 2002), 2-22.

${ }^{22}$ Filomeno Aguilar, "Citizenship, Inheritance, and the Indigenizing of "Orang Chinese" in Indonesia," Positions 9:3 (2001), 505.

${ }^{23}$ For a more elaborate overview of the sociohistorical processes see: Anthony Reid, ed., Sojourners and Settlers: Histories of Southeast Asia and the Chinese (St Leonard's, Australia: Allen \& Unwin, 1996); Robert Hefner, "Introduction: Multiculturalism and Citizenship in Malaysia, Singapore, and Indonesia," in Robert Hefner, ed., The Politics of Multiculturalism. Pluralism and Citizenship in Malaysia, Singapore, and Indonesia (Honolulu: University of Hawai'i Press, 2001), 1-58.
} 
between the natives and the Chinese only grew. ${ }^{24}$ This turned out to be crucial in the formative years of independence and thereafter.

(I)n assigning different ethnic groups to specialized positions in everything from agriculture to the opium trade, the Europeans crystallized the most essential of supraethnic categories: the distinction between indigenous Malayo-Indonesian "children of the soil" (Malay, bumiputera, Indonesian, pribumi) and "non-indigenous" or immigrant Asians (Indians and, especially, Chinese). This latter distinction was to be one of the most enduring categorical legacies of the colonial era. ${ }^{25}$

The division into Europeans, Foreign Orientals (such as the Chinese) and 'natives', each with different rights, by the colonial government continued during and after the formation of the nation state. ${ }^{26}$ Kleden $^{27}$ connects this ethnic stratification as practiced by the Dutch and taken over by the post-colonial government with governmental interference. Inter-ethnic relationships, he argues, only change into enmity and violence not as the natural consequence of the domination of one ethnic group over the other, but mainly because of government policy as such, with the fierce assimilation policy during the New Order as an example. The Assimilation Programme (Program Pembauran) can be interpreted as an attempt to construct a national identity by "identifying significant others", 28 the significant other being the non-pribumi Chinese. ${ }^{29}$ Obviously, this impacted on issues of ethnic identity and self-identification among the ethnic Chinese groups. The systematic othering of the ethnic Chinese in the New Order period did take on a meaning and life of itself, an anti-Chinese rhetoric expressed in many violent attacks. Chinese identities have been "always under erasure". 30

The identity politics under the New Order (and before) in fact resulted in an either or position of the ethnic Chinese; they could either be Indonesian or Chinese, but not both. As argued by Chang-Yau Hoon, "to be completely Indonesian, the Chinese had to give up all their "Chineseness". 31 The possibility of a hybrid identity, according

\footnotetext{
24 Ibid., 17-19.

25 Ibid., 19.

${ }^{26}$ For an extensive overview see: Filemeno Aguilar "Citizenship, Inheritance, and the Indigenizing of “Orang Chinese" in Indonesia," Positions 9:3 (2001); Robert Hefner, ed., The Politics of Multiculturalism. Pluralism and Citizenship in Malaysia, Singapore, and Indonesia (Honolulu: University of Hawai'i Press, 2001); Eugene Tan, "From Sojourners to Citizens: Managing the Ethnic Chinese Minority in Indonesia and Malaysia," Ethnic and Racial Studies 24:6 (2001).

${ }^{27}$ Dahana, "Pri and Non-Pri Relations in the Reform, Era: A Pribumi Perspective," in Leo Suryadinata, ed., Ethnic Relations and Nation-Building in Southeast Asia. The case of the Ethnic Chinese (Singapore: ISEAS Publications, 2004), 55.

${ }^{28}$ Chang-Yau Hoon, “Assimilation, Multiculturalism, Hybridity: The Dilemmas of the Ethnic Chinese in Post-Suharto Indonesia,” Asian Ethnicity 7:2 (2006), 151.

${ }^{29}$ It was during the interim presidency of Jusuf Habibie (1998/1999) that the official use of the terms pribumi (native; sons of the soil) and non-pribumi (non-native; immigrants - including ethnic Chinese) was abolished. It is interesting to note that the terms are still used by the interviewees in this paper, showing the ongoing legacy of these rather racial terms.

${ }^{30}$ Ariel Heryanto, "Ethnic Identities and Erasure. Chinese Indonesians in Public Culture," in Joel Kahn, ed., Southeast Asian Identities. Culture and the Politics of Representation in Indonesia, Malaysia, Singapore, and Thailand (London: I.B. Tauris Publishers, 1998), 104.

${ }^{31}$ Chang-Yau Hoon, "Assimilation, Multiculturalism, Hybridity: The Dilemmas of the Ethnic Chinese in Post-Suharto Indonesia,” Asian Ethnicity 7:2 (2006), 152.
} 
to Ien Ang the more logical outcome of a Chinese migrant's daily life in a nonChinese environment, was never a real option. ${ }^{32}$ In discussions on Chineseness in the Indonesian case, it is clear that the state (bureaucracy and instruments of government) has been one of the most important "variables which has contributed to the 'separateness' of the Chinese in Indonesia, particularly in Java". 33

A brief overview of such state mingling shows that Presidential Instructions and Decrees in 1967 limited the scope of Chinese traditions to the family worship house and required Indonesian ethnic Chinese to change their Chinese names into Indonesian ones in order that "such citizens shall be assimilated as to avoid any racial exclusiveness and discrimination". ${ }^{34}$ In 1966 the use of Chinese language and characters in newspapers and shops was prohibited and a much contested law was installed earlier (still causing quite some commotion at present) regarding citizenship, stating that Indonesian ethnic Chinese needed to have a SBKRI (Surat Bukti Kewarganegaraaan Republik Indonesia), evidence of the change of their Chinese names into Indonesian names, and a K-1 Letter to prove their Indonesian citizenship. ${ }^{35}$

After the fall of Suharto (1998) a few amendments have been made. Interim president Habibie (May 1998-October 1999) approved the formation of Chinese political parties and installed a Decree to stop the government's use of the words pribumi and nonpribumi. Abdurrahman Wahid (President from October 1999 until July 2001) abolished the law on the manifestation of Chinese cultural and religious expression in 2000. Megawati Sukarnoputri (in office July 2001-October 2004) issued a Decree that made Im Lek (Chinese New Year) a national holiday.

Amongst these changes, May 1998 took place. Many refer to May 1998 as a watershed in the history of Chinese Indonesians. It was after these violent events that various new citizenship initiatives were taken by the ethnic Chinese in order to form political parties, and activist or pressure groups. ${ }^{36}$ However, the majority appeared to want to be left alone, "doing what they have always done quietly", and preferred to "continue to go about their business, and hope and pray that their family will survive this multiple crisis". ${ }^{37}$ A relationship can be found in the perceptions held on the ethnic Chinese in present-day Indonesia, i.e. the idea that the ethnic Chinese are not true citizens and might turn their back on Indonesia whenever they feel like it, and

\footnotetext{
${ }^{32}$ Ien Ang, On Not Speaking Chinese: Living between Asia and the West (London: Routledge, 2001). The more recent revitalization of Chineseness in web logs and internet discussion groups among the younger generations of Chinese Indonesians might be seen as an expression of such essentialist or hybrid identity questions. See for instance: Sonja van Wichelen, "Silence, Absence, Loss: Re-sinicization in PostAuthoritarian Indonesia," Paper presented at the NIOD Indonesian Chinese Afternoon Meetings, (Amsterdam: Netherlands Institute for War Documentation, 13 December 2006).

${ }^{33}$ Leo Suryadinata, "The State and the Chinese Minority in Indonesia," in Leo Suryadinata, ed., Chinese Adaptation and Diversity. Essays on Society and Literature in Indonesia, Malaysia \& Singapore (Singapore: Singapore University Press, 1993), 77.

${ }^{34}$ Frans Winarta, "Racial Discrimination in the Indonesian Legal System: Ethnic Chinese and NationBuilding," in Leo Suryadinata, ed., Ethnic Relations and Nation-Building in Southeast Asia. The Case of the Ethnic Chinese (Singapore: ISEAS Publications), 72.

${ }^{35}$ Ibid.

${ }^{36}$ Mely Tan, "Unity in Diversity: Ethnic Chinese and Nation-Building in Indonesia," in Leo Suryadinata, ed., Ethnic Relations and Nation-Building in Southeast Asia. The Case of the Ethnic Chinese (Singapore: ISEAS Publications, 2004), 36.

${ }^{37}$ Ibid., 35.

Springer
} 
the belief that the ethnic Chinese have always benefited disproportionately from economic opportunities granted by Suharto. ${ }^{38}$ The ethnic Chinese themselves feel "they are discriminated against even though they have Indonesian citizenship and have chosen the country as their homeland". 39

From the above it can be concluded that ever since colonial times the ethnic Chinese in Indonesia have been contested in their ethnic identity and their related citizenship. Their position within the newly built nation state has been one of exclusion (and discrimination), which is underlined by the various restrictive laws that have been installed. After the tragedy of 1998, some groups of ethnic Chinese felt it was time to renew some of their citizen's rights but sources indicate that this was only a small proportion of the heterogeneous group referred to as ethnic Chinese. Their long experience with state domination and discrimination is considered to be an important reason for the large majority of the ethnic Chinese to prefer to remain 'invisible', keep silent, and go their own way. The question is whether this is indeed the case. Has the long experience of discrimination and suppressed ethnic identity led to the demise of 'being Chinese'? Or is the newly created space for expressing ethnic identity experienced as an opportunity for revival? What do the Chinese Indonesian entrepreneurs in this study have to say about this issue?

\section{Discursive Practices on Chineseness}

The reformation time that started with the fall of former president Suharto in 1998, was experienced by the older generation interviewees as an opportunity to revive Chineseness. Most often mentioned were the revival of Chinese culture, Chinese values and morals and Chinese organizations. Recurring themes were taking pride in being Chinese and the need to reestablish Chinese morals such as solidarity, respect, trust, the family, and relationships. The interviewees felt that the last 30 years have led to the collapse of these values; the time has come to stop this process and become more active and outspoken.

It might be that the focus on Chinese culture is coming back. We have not been able to discuss or focus on this for 32 years. Now we are all pleased; new interests arise around cultural issues of the Chinese. There is a sense of euphoria; that Chinese traditions are allowed again. [Brenda]

The last 30 years in Indonesia have resulted in a lack of knowledge on Chinese values and culture among our younger generation. There was in those years a rule that the Chinese were not allowed to use their Chinese language in public places. As a result our culture was crushed (hancur). We want to focus on Chinese culture, not exclusively, but we want revive the idea among the Chinese that Chinese culture is a beautiful culture. We want to hand this over to the next generation: morality, trust. The Chinese who have migrated all over the globe have been able to survive and do well because of their culture, because of

\footnotetext{
38 Amy Freedman, Political Participation and Ethnic Minorities. Chinese Overseas in Malaysia, Indonesia and the United States (London, New York: Routledge, 2000), 117.

39 Ibid.
} 
their moral values and trust. Solidarity is very important because we are a migrating people. This has been important from the start. We need the solidarity among ourselves in order to be able to build a new life. Without solidarity we get crushed. Having respect for other people, focus on the family. This is what we need to teach the next generation. [Benni]

Central in this revival is a focus on Chinese material culture and language. However, reinstalling Chinese organizations and even Chinese schools is considered equally important.

Since the fall of Suharto two of the major Chinese tribe groups have set up an organization for their tribe members, both headed by well-known businessmen. During the reformation time the Chinese of my generation, who are all alumni of Chinese schools, also started an Alumni organization. The aim is to bring together the Chinese who went to Chinese schools but it is not exclusively for them. It is a vehicle to organize the Chinese in Yogya. Many are still somewhat afraid because in former times when we wanted to get together the police disturbed us. We were asked why we were getting together and people were interrogated. Paying some money usually could solve this. As a result there is still fear among the Chinese to get involved in organizations. That is why we now use the title Alumni. Our vision is not really clear yet but we started out with some gotong royong; help each other. But we are also heading in the direction of a Chinese organization in order to correct the wrongs being done to the Chinese, to get rid of the discrimination against the Chinese. We want the same rights as other Indonesians. We also want to readdress our culture. Furthermore we also intend to build a Chinese school because we are not at all satisfied with the school system in Indonesia. You can say that there are no morals taught in the Indonesian schools. [Benni]

When asked what kind of morals and values they consider important, all members of this group stress trust and good relationships.

Chinese morals that are important are: sinyong, trust and guanxi, good relationships. In our life we have to build good relationships. This is still strong among my generation of Chinese, among the generation after me this is already breaking down. We try to revive this via these Chinese organizations. In former times we used to get together, help each other, exchange ideas, and build friendships. But since Suharto we had a very difficult time to organize. We tried to do so via sport organizations and via religious activities. The legal way. Although in these gatherings we still could talk about Chinese issues it was quite limited. It was very difficult. But as a result we could restart quite quickly after Suharto fell down. [Benni]

Two things stand out. First of all, notwithstanding the ban on getting together as ethnic Chinese, some did continue their gatherings under the banner of more legitimate organizations. As a result some organizational structures were still in place and could be used to restart Chinese organizations. Secondly, the older generation has an urge to reinstall Chinese culture, from language and art to values and morals. It is felt that the restrictions on their Chineseness almost resulted in a 
degeneration of their 'culture', of 'being Chinese' and that it has been mainly the young who have been the victims thereof, as they were born under a system where any display of their ethnic identity could cause imprisonment. This group of older Chinese Indonesian entrepreneurs certainly does not display the often heard claim that they prefer to stay invisible and want to be left alone. After a long period of what they call the destruction of Chinese culture and organizations, this generation aspires to revive the idea that Chinese Indonesians have a culture of their own (as different from what they call Indonesian culture) of which they can be proud as ethnic Chinese, and there is an interesting strive to bring it to life now that there is room; especially for the benefit of the generation of their children and grandchildren.

However, as one interviewee pointed out: "The Chinese are never uniform; we are not a homogeneous group". Nevertheless, now that there is room for people to organize themselves as 'the ethnic Chinese', common ground is found in expressed shared cultural values and morals. The fact that the different tribe/dialect groups start to reinstall their own organizations is an important feature that should not be omitted.

\section{Chineseness and Doing Business}

Before turning to the discourse of the interviewees on 'doing business the Chinese way', it is important to first look at the ongoing debate concerning the economic position of ethnic Chinese in Southeast Asia, and Indonesia in particular, as it gives the necessary context for the topic under discussion here.

Ethnic Chinese communities can be found all over the world, however, the largest group of ethnic Chinese living outside China can be found in Southeast Asia; some 25 million - of which more than 7 million alone live in Indonesia. ${ }^{40}$ Apart from their predominance in percentages, for long it has been argued that the ethnic Chinese in Southeast Asia also exhibit dominance in economic terms. Some hold that ethnic Chinese businesses in Malaysia, Indonesia, Thailand and the Philippines account for 40 to $60 \%$ of total GDP, whereas the ethnic Chinese are said to control some $80 \%$ of Indonesia's and $40-50 \%$ of Malaysia's corporate assets. ${ }^{41}$

The suggestion of the dominant influence of Chinese capital in Southeast Asia is, however, not uncontested. It is argued that lack of empirical evidence on the small and medium sized enterprises, in which large numbers of ethnic Chinese in fact are active, makes any claim on such economic dominance rather premature. $^{42}$ Equally, the literature on ethnic Chinese business success in Southeast

\footnotetext{
${ }^{40}$ Laurence Ma, "Space, Place, and Transnationalism in the Chinese Diaspora." in Laurence Ma \& Carolyn Cartier, eds., The Chinese Diaspora. Space, Place, Mobility, and Identity (New York: Rowan \& Littlefield Publishers, 2003), 13.

${ }^{41}$ Henry Yeung and Kris Olds, eds., Globalization of Chinese Business Firms (Hampshire: Macmillan Press Ltd., 2000), 7-9. For a critique on corporate ownership figures, see: Terence Gomez and Micheal Hsiao, "Introduction: Chinese Business Research in Southeast Asia," in Terence Gomez and Michael Hsiao, eds., Chinese Business in Southeast Asia. Contesting Cultural Explanations, Researching Entrepreneurship (London, New York: RoutledgeCurzon, 2004), 9-10.

42 Terence Gomez and Micheal Hsiao, "Introduction: Chinese Business Research in Southeast Asia," in Terence Gomez and Michael Hsiao, eds., Chinese Business in Southeast Asia. Contesting Cultural Explanations, Researching Entrepreneurship (London, New York: RoutledgeCurzon, 2004), 3-4.
} 
Asia is very quiet on the reverse, that is business failure, as this would be the flip side of the same coin. ${ }^{43}$

The omnipresence and acclaimed success of ethnic Chinese business ventures in Southeast Asia are often linked to three issues. ${ }^{44}$ First of all, the key role of particularistic relationships of trust (guanxi and xinyong), of patriarchal authority and filial norms, and of specific Confucian values such as filial piety, moral obligations, and loyalty. These values are said to be constitutive of successful business practices. Secondly, the importance of bottom-up organizations and associations such as kinship networks, trade guilds, dialect groups, and mutual aid organizations during the start-up phase of a business. And thirdly, the historical disposition of the ethnic Chinese in colonial and post-colonial southeast Asia, such as the familiarity of the Chinese immigrants with credit institutions and the use of money, their middlemen status (collecting taxes and being 'partners' in the colonial opium trade), and the various rent-seeking arrangements of political elites with the ethnic Chinese. In short, the success of the ethnic Chinese in Southeast Asia is to be found in their "legendary qualities of enterprise, hard work, frugality, family solidarity, education and other "neo-Confucian" or "entrepreneurial" virtues". 45

As briefly touched upon in the introduction, these arguments are not without their critics, and the plea to be very careful with Chineseness-based explanations of Chinese capitalism and culturalist Chineseness arguments was made by Dirlik already in the mid1990 s. $^{46}$ In later years scholars argued that the cultural factors that are employed to explain business success can be used to come to very different and even opposing results as well, ${ }^{47}$ and that "Chinese economic behaviour in contemporary capitalism is motivated by profit maximisation, for which 'Chinese-ness' may or may not be one of the means deployed". ${ }^{48}$ Meanwhile historians pointed out that Chinese immigrants seldom had affinity with the literati values of Confucian doctrines. ${ }^{49}$ Furthermore, the

\footnotetext{
${ }^{43}$ Vivienne Wee, "A Cultural Economy of Ethnicity and Capital in the Regionalisation of China and Southeast Asia," in Michael Jacobson, ed., "De-Essentialising 'Chinese Capitalism' in Southeast Asia," NIASnytt 3 (2004), 6.

${ }^{44}$ See: Robert Hefner, ed., Market Cultures. Society and Morality in the New Asian Capitalisms (Boulder Colorado: Westview Press, 1998); Jamie Mackie, "Business Success among Southeast Asian Chinese: the Role of Culture, Values and Social Structures," in Robert Hefner, ed., Market Cultures. Society and Morality in the New Asian Capitalisms (Boulder Colorado: Westview Press, 1998), 129-146; Terence Gomez and Michael Hsiao, eds., Chinese Business in Southeast Asia. Contesting Cultural Explanations, Researching Entrepreneurship (London, New York: RoutledgeCurzon, 2004); Thomas Menkhoff and Solvay Gerke, eds., Chinese Entrepreneurship and Asian Business Networks (London, New York: Routledge, 2004).

${ }^{45}$ Jamie Mackie, "Business Success among Southeast Asian Chinese: the Role of Culture, Values and Social Structures," in Robert Hefner, ed., Market Cultures. Society and Morality in the New Asian Capitalisms (Boulder Colorado: Westview Press, 1998), 133.

${ }^{46}$ Arif Dirlik, "Critical Reflections on 'Chinese Capitalism' as Paradigm," in Ampalavanar Brown, ed., Chinese Business Enterprise Volume 1 (London: Routledge, 1996), 26-27.

${ }^{47}$ Terence Gomez and Micheal Hsiao, "Introduction: Chinese Business Research in Southeast Asia," in Terence Gomez and Michael Hsiao, eds., Chinese Business in Southeast Asia. Contesting Cultural Explanations, Researching Entrepreneurship (London, New York: RoutledgeCurzon, 2004), 19.

${ }^{48}$ Vivienne Wee, "A Cultural Economy of Ethnicity and Capital in the Regionalisation of China and Southeast Asia," in Michael Jacobson, ed., "De-Essentialising 'Chinese Capitalism' in Southeast Asia," NIASnytt 3 (2004), 5.

${ }^{49}$ Gungwu Wang, Community and Nation: China, Southeast Asia and Australia (Sidney: Allen and Unwin, 1992).
} 
above-mentioned lack of studies on ethnic Chinese SME's in their own right, and on whether, because of their size, they subscribe to what has been labelled cultural styles of business, or in fact are more productive because of their size and lack of comprador relationships, was left in the open. ${ }^{50}$ The position that it might not have been exclusively the intra-ethnic relationships that condition ethnic Chinese entrepreneurship has been brought to the fore by Jacobson for Manado, Indonesia, and by Gomez for Malaysia. ${ }^{51}$

Hence the field is very much in motion and new empirical findings are currently appearing (such as this volume) that might shed a different light on the 'Chineseness factor' in ethnic Chinese business practices in Southeast Asia.

A final word concerns the study of ethnic Chinese entrepreneurship in Indonesia. Whether or not there is an economic domination and to which extent this is related to a particular Chinese way of doing business in which Chineseness matters, for the Indonesian case it is important to point out that the ethnic Chinese were historically not allowed to occupy civil servant positions or to own land. In the New Order period (1965-1998) the ethnic Chinese "were prohibited from participating fully in political, civic and military affairs" $" 52$ and hence mostly ended up in entrepreneurial and business occupations, the private sector of the economy where the majority in fact are small shop keepers and traders. Only some ethnic Chinese, the so-called cukong - a Hokkien term to refer to ethnic Chinese businessmen who cooperate with the power elite $^{53}$ — were chosen as business partners by the Suharto regime and received favours not accessible to others. This very small group of cukong became synonymous of 'the ethnic Chinese' in general and especially the display of their exorbitant wealth caused much of the 'hatred' directed against the ethnic Chinese as an ethnic group. ${ }^{54}$

Indonesia is not different from other Southeast Asian countries in lacking empirical studies on the operation of Chinese small and medium sized companies

\footnotetext{
50 Terence Gomez and Micheal Hsiao, "Introduction: Chinese Business Research in Southeast Asia," in Terence Gomez and Michael Hsiao, eds., Chinese Business in Southeast Asia. Contesting Cultural Explanations, Researching Entrepreneurship (London, New York: RoutledgeCurzon, 2004).

${ }^{51}$ Michael Jacobson, "On Entrepreneurship and Ethnic Belonging. Ethnic Chinese SME Entrepreneurs in Southeast Asia," in Michael Jacobson, ed., "De-Essentialising 'Chinese Capitalism' in Southeast Asia," NIASnytt 3 (2004), 11-13; Terence Gomez, "De-Essentialising Capitalism: Chinese Networks and Family Firms in Malaysia," in Michael Jacobson, ed., "De-Essentialising 'Chinese Capitalism' in Southeast Asia," NIASnytt 3 (2004), 8-11.

52 Amy Freedman, Political Participation and Ethnic Minorities. Chinese Overseas in Malaysia, Indonesia and the United States (London, New York: Routledge, 2000), 3.

${ }^{53}$ Leo Suryadinata, The Culture of the Chinese Minority in Indonesia (Singapore: Times Books International, 1997), 8.

54 The most well-known works on the ethnic Chinese minority in Indonesia are Charles Coppel, Studying Ethnic Chinese in Indonesia (Singapore: Singapore Society of Asian Studies, 20022); Charles Coppel, "Special Issue Foreword," Asian Ethnicity (special issue on Chinese Indonesians) 4:3 (2003), 327-336; Leo Suryadinata, "The State and the Chinese Minority in Indonesia," in Leo Suryadinata ed., Chinese Adaptation and Diversity. Essays on Society and Literature in Indonesia, Malaysia \& Singapore (Singapore: Singapore University Press, 1993), 77-100; Leo Suryadinata, The Culture of the Chinese Minority in Indonesia (Singapore: Times Books International, 1997); Leo Suryadinata, ed., Ethnic Relations and Nation-Building in Southeast Asia. The Case of the Ethnic Chinese (Singapore: ISEAS Publications, 2004); Leo Suryadinata, "Ethnic Relations and State Policies: The Case of Contemporary Indonesian Chinese," in Lee Guan Kin ed., Demarcating Ethnicity in New Nations: Cases of the Chinese in Singapore, Malaysia, and Indonesia (Singapore: Konrad-Adenauer Stiftung \& Singapore Society of Asian Studies, 2006), 211-226.
} 
and on the factors that have helped to sustain their businesses. ${ }^{55}$ Lien and Tan raise the issues of identity: "Will they be more Indonesian-oriented, Chinese-oriented or adopt a view of themselves as borderless world citizens, with their only consideration being the desire to do well in business?". 56 And finally they wonder about the assumptions of changing business styles among the younger generations of Chinese Indonesians. The manner in which the Chinese Indonesian entrepreneurs in this study narrate the broader issue of ethnic identity in business practices - the role and meaning of Chineseness in business practices - shall be discussed next and might serve as an addition to both the empirical knowledge gaps mentioned above and to new insights into the role of Chineseness in doing business.

\section{Discursive Practices on Chineseness and Doing Business}

The expressed common and preferred business practice by the entrepreneurs in this study is 'doing business with other Chinese'. Although many of the businesses in Indonesia are in the hands of the Chinese, as they themselves explain, there is more to it. This group expresses the sharing of a common view and practice in doing business that they refer to as 'Chinese'. This is often explained in stark contrast to indigenous ways of doing business, with the 'Chinese way' being more businesslike (and often qualified as better). The common business acumen is considered of major importance and has been and is for many the key to setting up a business but also for running it. However, the discourse also shows signs of relativism: certainly not all 'Chinese' can be trusted and 'the Chinese' are often just focused on profits. Furthermore, it is interesting to note the fair amount of remarks about the younger generations no longer adhering to or practicing such 'common' Chinese business customs.

The business practices considered central to 'the Chinese way of doing business' are the use of personal networks, trust, and trustworthiness.

I think tribe (kesukuan) is important for the Chinese. Trust is very important, but how do we build trust? It starts with tribe, this leads to a familiarity that shapes a bond and sympathy and this opens the road to do business together. [Brenda]

Personal networks are very important. For instance I contact someone by telephone outside Yogya, also a Chinese. I get this name from a friend. I only get his Chinese name. We talk informally, using informal Chinese language. If I contact this person he does not immediately trust me. He will check me out; he will try to find references, he will try to find other people who might know me. So we have to invest time to reach the right feeling (cocok). You can call it trust building. That is business here; we do not work with contracts because we are

\footnotetext{
55 Diao Lien and Mely Tan, "Indonesia," in Terence Gomez and Michael Hsiao, eds., Chinese Business in Southeast Asia. Contesting Cultural Explanations, Researching Entrepreneurship (London, New York: RoutledgeCurzon, 2004), 141-145. A recent correction to this omission for the Malaysian case is the $\mathrm{PhD}$ thesis by Zwart. See: Esther Zwart, In Pursuit of Comfort. The Transnationalisation Process of Malaysian Chinese Small and Medium Enterprises, PhD thesis, (Amsterdam: VU University Amsterdam, 2006).

56 Diao Lien and Mely Tan, "Indonesia," in Terence Gomez and Michael Hsiao, eds., Chinese Business in Southeast Asia. Contesting Cultural Explanations, Researching Entrepreneurship (London, New York: RoutledgeCurzon, 2004), 144.
} 
never sure if these are followed to the letter. If we want to bring a case to court it never gets resolved and it costs a lot of money. That is Indonesia. [Harri]

I mostly work with Chinese; trust is very important among the Chinese. We work via recommendation. Before a deal, first information is sought via other Chinese on the reputation and most importantly on the credibility of the other. [Yunas]

In business, personal networks are most important, and these are most often also the Chinese personal networks. I have to admit that personal networks are very important, but it can not be restricted to certain social strata, potions, culture, or ethnicity. I also started my business from personal networks. The pribumi probably use personal networks as well but the family network is far stronger among the Chinese than among the pribumi. [Go]

These personal networks are not only a basis for access to capital and goods; often the use of these networks is seen as synonymous with trust and trustworthiness and inherently different from pribumi ways of doing business. ${ }^{57}$

In general Chinese seek other Chinese for businesses. The chance that I start a business with a local (pribumi) is very small. This is because their sense of business is very different. If Chinese people make a profit they save it in order to open a new store or to invest again, buy new equipment but also for educational purposes. When needed, there is money. However, Indonesians if they make a profit often they want to spend it on other things than the business. That has a huge impact on doing business. If we have a profit we save it first. If a new business opportunity comes up we can react immediately because we do not need to borrow money from others. But the Indonesians reason: we have worked hard, now we want to enjoy our profit. They think differently. This makes it very difficult to work with them. [Harri]

Most of my business relations are with other Chinese because the pribumi have different feelings of responsibility. For a Chinese it is important that if he does not live up to his financial promises he will loose his name. Responsibility is very important. If this is jeopardized the relationship ends. [Herman]

Trust and trustworthiness (often in combination with credit-worthiness) appear in all the interviews. Sinyong is the term that is used for this broader understanding of trust by many of the interviewees. ${ }^{58}$

Trust is important for Chinese people. Trust networks are the basis. If the trust network is strong everything is possible. [Brenda]

\footnotetext{
${ }^{57}$ It is important to remark that when using the words pribumi or Indonesians, the interviewees often make a direct reference to the Javanese. The fact that my case is located on the island of Java, the political and economic centre of Indonesia, and in Yogyakarta, seen as the centre of high Javanese culture, might contribute to these rather strong stereotypical expressions.

${ }^{58}$ In most of the literature the word used is xinyong, translated by Mackie as trust, creditworthiness. Sinyong might just be the Indonesian version of the word. See: Jamie Mackie, "Business Success among Southeast Asian Chinese: the Role of Culture, Values and Social Structures," in Robert Hefner, ed., Market Cultures. Society and Morality in the New Asian Capitalisms (Boulder Colorado: Westview Press, 1998), 130.
} 
When I was still working for my father I got to know many traders. Quite a few of them told me: if you open your own business I shall give you some materials to sell, you can pay back later. These owners already trusted me, sinyong, because of my father. This trust has been very important in setting up my own business. [Sri]

A lot is based on guanxi. For access to capital this is still important because it is not spoken for that the bank will give it. Access to capital is much easier through my trust relationships. [Benni]

In former times while doing business nothing was written down or made into contracts. Everything went by word of mouth, this is Sin Yong; sin means percaya; yong means memakai; in other words: using trust. [Alief]

The trust relationship is based on the fact that we know each other but we have to have a good relationship. If I want to approach someone I do not know yet and who does not know me, this has to go via a close friend of this person. Otherwise it is not possible. This will bring the two together. The community knows who can be trusted and who not. [Benni]

Although this generation mentions the importance of such trust and credit networks, they also frequently make remarks about the younger generation who does not exhibit these values and practices.

The younger Chinese are not really trustworthy. They have not been to Chinese schools and thus are difficult to trust. Those who have been to Chinese schools received an education on morals. The later generations who went to Indonesian schools did get the same lessons. One of the most important moral lessons according to me is: don't ever forget the people that have helped you. This is very strong among the Chinese with that background. Such morals are disappearing especially among the younger Chinese. [Alief]

Next to guanxi and sinyong, helping each other (gotong royong) is important among the Chinese of my generation. Take me as an example. Because the Chinese schools closed around 1965 I was forced to find a job. My parents only had a small business, just enough to keep the family going. So I had no start-up capital. Based on guanxi and sinyong, and with the culture that the Chinese always help each other I was able to organize a savings group and start a business of my own. This is trust and tribe based. [Benni]

Hence, good relationships, trust- and creditworthiness, responsibility and good name, and helping each other are mentioned as important business values and ways in which access to capital and partners was established. However, it is acknowledged that helping the other is much easier if you are not in the same line of business and that the importance of making a profit can jeopardize the expressed business values.

In business, the Chinese can be very pragmatic. The most important thing is profit. If they have a good reason, such as seeking profit, the Chinese might even do business with the pribumi. But it does not really happen a lot. What the Chinese try to do is to become good friends with pribumi officials, to get things done, to help them with permits. Maybe being a minority has taught the Chinese to be opportunistic and pragmatic at the same time. [Brenda] 
The Chinese business networks still exist but much depends on competition as well. For instance, I am in the medicine business, pak A. is in the tile business. I am having some money problems; I can call A. and ask him for some money. That is no problem; we have a strong trust relationship and are also in different businesses. My generation is still doing this. [Benni]

The discourse is filled with qualifications that make 'the Chinese way of doing business' the best way. This is often linked to a history of migration.

Our forefathers migrated from China with nothing; only their shirts. They were courageous and had spirit. They went everywhere. They started to change what was around them; with hands and head. Also with trade one can create richness. But thinking ahead is very important, I have the feeling the pribumi do not think about tomorrow as we do, I don't know why. [Benni]

The Chinese are very dynamic, they are never satisfied with the way things are. They always want more. You can either judge this as positive or negative. It is the same to me. This is the way it is. We are not satisfied with a status quo. Already my parents told me this. This is because the Chinese people here are migrants, people who wanted to change things, people who were brave enough to take many risks, to leave behind everything without knowing if they would be successful. That is the background. [Harri]

The picture that emerges from the above is one in which the older generation juxtaposes itself against the local population (pribumi) but also against the younger generation of Chinese Indonesians. There is an explicit us versus them positioning and the younger generation is seen to have become part of the 'them', influenced as they are by the Indonesian surroundings and culture in which they grew up in which there was no room for anything 'Chinese'.

This discourse stresses certain Chinese business values (guanxi, sinyong, gotong royong) that are strongly related to the migration history but are felt to be on the verge of disappearing among the younger generation because the latter have grown up in an Indonesia where these values are not deep-seated; and there is a strong stereotyping of a Chinese way of doing business versus local ways of doing business, in which the former is seen as the more successful way. Even tough several nuances are made, such as the pragmatism and the profit focus which might jeopardize certain acclaimed values; the discursive practices employed express a strong belief in the business practices of the older generation of Chinese Indonesian entrepreneurs, as they have been constitutive in setting up a business in the small and medium sized sector and in running it. In the next section I shall elaborate on this older versus younger generation discourse.

\section{Generational Differences}

The generational differences as expressed by the older generation of Chinese Indonesian entrepreneurs are an interesting phenomenon that is worth a further exploration. By understanding a generation as individuals who share a "common location in the social and historical process", in which the latter potentially provides 
them with overlapping experiences, beliefs, and views, it follows that with each new age group there is the potential for new attitudes and new modes of thought. ${ }^{59}$ This argument is helpful in a context in which the generations are confronted by rather different experiences (as the room for maneuvering as an ethnic minority has been different for the different generations of Chinese Indonesians). By extending the biological meaning of the concept generation (people born in the same time interval) to a more socio-historical meaning (people who share the experience of several social and historical processes), we can explain certain phenomena in society, especially ones that come to the fore in a rapidly transforming society such as Indonesia. Mannheim observed that especially in rapidly changing societies new attitudes and new generation styles develop, "the quicker the tempo of social and cultural change is, then, the greater are the chances that particular generation location groups will react to changed situations by producing their own entelechy". 60

In the above various remarks were made by the older generation concerning the change of business conduct among the younger generation of Chinese Indonesians. Two issues came up that the older generation considers as indicative of generational changes in the Chinese way of doing business. First, the accumulation of start-up capital, and second, the aspirations of taking over family businesses related to educational changes.

\section{Discursive Practices on Chineseness and Generational Divides}

One of the interviewees explained at length that the way in which capital is assembled for starting a business has gone through various changes that for him represent the changed climate and the changing role of Chinese values and morals in the business practices of the younger Chinese Indonesians today.

In former times we would use an arisan [a form of rotating saving and credit association] for start-up capital. I would collect money from my trust group and would pay back the moment my business was doing well. If my business did not go well I did not have to pay back the money, at least not if I worked hard and did not use the money for gambling and drinking. The arisan that followed is a bit different. I go to all my friends and ask them for a certain amount of money. The moment the business start-up is conducted I start paying back the person whose name is drawn, as in a lottery; this is done once a month. There is no interest. This arisan is still active among my generation. The one who starts the arisan is in the centre; the others only have to trust him. If the business goes bankrupt those who joined do not protest. But the person who started it will work very hard to return all the money. If the money is kept for other purposes the trust relationship ends. Right now businessmen are not enthusiastic about this system because there is no profit. So a new arisan was developed which is more business focused; there is a profit involved in the form of interest. This is related to the fact that the idea of helping people is changing: I might experience a loss,

\footnotetext{
${ }^{59}$ Karl Mannheim, "The Problem of Generations," in P Kecskemeti, ed., Karl Mannheim. Essays on the Sociology of Knowledge (London: Routledge \& Kegan Paul Ltd., 1952), 291.

${ }^{60}$ Ibid., 310.

글 Springer
} 
why help out for nothing? This is the thinking now. This is related to outside cultural influences, but also because there is more business competition. [Benni]

The other issue, one that is rather common in discussions on generational change in family businesses, is the influence of the changing educational background and the related ideas on how to run a business.

Doing business is not something you can inherit easily. In case the children take the effort to understand and follow the business practices of their parents then maybe $75 \%$ will succeed. However, often the children have different ideas and that might result in the collapse of a successful business. They do not want to follow the business manners of the parents/father. The general developments are also part of this. The parents/father did everything alone and kept everything in their/his own hands, now there are managers. The children don't understand why the father was successful. By the time they take over, it becomes problematic. Some however do a better job. One of the problems is that the children get their diplomas abroad, MBA's from other countries. There they learn how to become professional. However, management and professionalism is only a tool, it is not yet a successful business. How to run a successful business cannot be studied abroad. So according to me the fact that the children do not focus on the business practices as conducted by their father, prevents them from understanding the success. In fact they might be smarter but business is not just a science. [Harri]

Many present-day Chinese parents are a bit troubled. They have worked hard to have their children educated, often abroad. But with this education these children do no longer wish to take over the family business. With their degree they can make a lot more money working for a foreign company; it jeopardizes the family business. However, the Chinese businesses try to move ahead with the changing times as well. We used to be mainly in retail but we are moving ahead as well. We started with small shops for daily necessities, but now we open supermarkets. So even though we still have family businesses we follow the changes and we also start to recruit other people. [Benni]

The narratives of the older generation of entrepreneurs often reflect on the differences between their business conduct and morals and those of the younger generation. There are disappointment and a feeling of loss in their voices, especially the loss of Chinese business practices, values and customs. Is this merely an older generation expressing that things were much better in the past (as is seen as a common generational phenomenon)? How about this younger generation? Do they fit the discourse of the older entrepreneurs?

The younger entrepreneurs all explain that 'Chinese traditions' are no longer important for them. In most cases expressions of what they refer to as Chinese traditions are restricted to Chinese New Year and eating Chinese food. In their daily life they state that they feel Indonesian.

If I had lived in China I would have loved China. But I was born in Indonesia, so I am Indonesian. If people ask me where I am from I always reply that I am Indonesian, not that I am Chinese. [Oskar] 
We, the younger generation are more influenced by the local culture and therefore maybe less Chinese. I think we can say that Chinese family values are more and more disappearing with each new generation. [Samsul]

I do not belong to a Chinese group, I live in Indonesia, the difference between Indonesians and Chinese is not important for me. [Rina]

There are no real Chinese traditions that we still follow; it is not strong anymore. At most during Chinese New Year we great each other in Chinese and the younger children go to the older relatives to offer good wishes. But that is all. We are in fact Indonesians; there is already an Indonesian flavor to our culture. [Aris]

Interestingly enough, in matters of business being Chinese does become important. All express that when it comes to doing business, Chineseness does make a difference. In this regard their discourse resembles very much the discourse of the older generation.

Chinese people have a better eye for business; Chinese are more focused on how to make the business into a success whereas the Javanese are more focused on getting rich as quickly as possible. [Oskar]

When in business it is not okay to relax. The Chinese never do, a real entrepreneur is ready to take risks and not to sit back and feel comfortable. [David]

In fact for me, being Chinese equals hard work and being in business. [Agus]

When I was asked to join the family business, I did so. However, it was not really a success and in fact I left again with many quarrels after two years. This was because my mother, who in fact runs the business, felt she became useless because I started to work with computers while she did the bookkeeping still by hand. She also disliked the choices I made in management and in recruiting personnel; she could not understand why I was only sitting behind a desk in the back office all the time instead of being at the counter in the store to oversee the business. We ended up quarrelling all the time and so I left. I was cut off financially as well. It took several years before I understood that certain business practices of my mother are quite important, so I returned and now we work side by side. I learned that the Chinese business way of always being involved in relationships is very important; one never knows when these come in handy. [David]

I just trust the Chinese more in doing business, many Chinese are entrepreneurs, and they are keen businessmen and better in doing business. [Rina]

In business, working with Chinese is just the better option because they have more business talent. At the same time there is mutual understanding, that's a nice way to do business. [Budi]

Equally, when it comes to marriage partners both generations share the idea that it is better to marry within their 'own group'. Phrases like there is a better match between like-minded people, that with a stranger it is more complicated to have the marriage succeed, and that the difference between the pribumi and Chinese is just too big, were often mentioned. An example comes from Budi, a younger generation Chinese: "Even though I can say we care less about being Chinese it is in fact strange that we do prefer to marry a Chinese. I would say that almost $99 \%$ of the 
Chinese look for a Chinese partner; it has to do with different understandings". This cross-generational preference for marrying within the ethnic group might be an indicator that intra-ethnic relationships are still predominant among the Chinese Indonesians, not only in personal matters but also, as has been shown above, in business matters.

\section{Concluding Remarks}

This paper discusses the role and meaning of Chineseness in business conduct among different generations of Chinese Indonesian entrepreneurs active in small and medium sized enterprises. This issue was raised in order to inspire the ongoing debate concerning the characteristics of ethnic Chinese business practices in Southeast Asia with insights into topics that are often lacking in the debate: the voice of those concerned, the business practices of Chinese Indonesian entrepreneurs in the SME sector, and generational differences. Instead of describing the enterprises, the capital flows, and products (which are all important features) in this paper I have opted for a discursive approach as this informs us not only on the business practices sec but in particular on the ideological, socio-cultural, and political bearings that lie underneath them; dimensions that cannot be ignored if we discuss the matter of ethnic identity and nation state policies.

The last few decades, scholars have been engaged in debates on the particulars of the intra-ethnic business ties of the ethnic Chinese in Southeast Asia. Much of this debate evolved around trying to explain the reasons for an acclaimed business success - often in comparison with indigenous entrepreneurs; and mostly in the context of the economic boom years in Southeast Asia and the growing economic position of China. Apart from this success story and the question to what extent Chinese cultural values, historical and institutional attributes, and/or economic positions are the main drivers thereof, the topic has raised interest among scholars because of apparent controversial concerns: in many Southeast Asian nations the ethnic Chinese are an ethnic minority but predominant in entrepreneurial activities. Furthermore, they are not very visible in the political arena and in some countries (Indonesia) they are confronted with heavily contested citizenship positions. The question was raised whether this kind of study had not created a nonexisting essentialized ethnic Chinese businessperson.

This paper has taken up the challenge to explore the role of Chineseness in business conduct in order to reflect on the essentializing and de-essentializing tendencies in the literature and the culturalist-criticalist debate linked to it. To do so, a discursive and situational approach has been applied; ample attention is given to what Chinese Indonesian entrepreneurs themselves have to say on issues that are debated in the literature: How do they describe their business conduct and does their discourse reveal anything of shared cultural, Chinese business practices? As such, the voices of older and younger generation Chinese Indonesians were incorporated, as ethnic identity is never static and the different historical contexts in which the generations grew up might have impacted on their feeling and being Chinese both in personal and in business matters.

Apart from taking these different historical contexts into account by giving voice to different generations, the role of the Indonesian nation state has been so incisive in ethnic identity politics that it cannot be left out of the discussion. The position of the 
ethnic Chinese born and raised in Indonesia has always been rather insecure, both in material and in immaterial terms. Already during the Dutch colonial period, ethnic Chinese were singled out as immigrant Asians or Foreign Orientals, in the formative years of the Indonesian republic the issue of Indonesian citizenship for the ethnic Chinese was heavily debated, and under the reign of former president Suharto's New Order (1965-1998) Chinese Indonesians were confronted with a variety of discriminative laws. The explicit manipulation of ethnicity by the state for its own purposes is clearly in play here. For more than 30 years being Chinese meant keeping silent and invisible. Obviously this has had an impact on the expression and feelings of being Chinese. This paper has explored the extent to which this is the case in business conduct.

What can be concluded? The discursive practices on ethnic identity and the newly created room to express Chineseness show that the older generation (those who went to Chinese schools during their youth in Indonesia) in particular has an urge to bring back attention for Chinese traditions, language and material culture as a culture to be proud of. There are signs of setting up organizations based on dialect/tribe groups with the aim to revive Chinese morals such as helping each other and trust-building. Among the younger ethnic Chinese these are not issues that seem to matter much. They express to be and feel Indonesian and do not seem to be interested that much anymore in Chinese traditions (like going to the temple or to graves of forefathers) in general.

The discourse on Chineseness and business practices however, reveals that both the younger and the older generation entrepreneurs stress the importance of 'being Chinese' in business mentality and practice. What the discursive practices have in common is that the Chinese are considered as better entrepreneurs compared to non-Chinese entrepreneurs. The former are more business oriented, more focused on working hard and always have the success of the business in the forefront. Notwithstanding this overlap in thinking that the Chinese Indonesians are the better business people, the older generation expresses a disappointment that the younger generation no longer makes use of the business practices they consider important and 'Chinese', such as sinyong, guanxi, and helping without direct benefits. The older generation 'blames' the different (non-Chinese) cultural influences in which this younger generation grew up. However, they also feel that their own aspirations to have their children educated abroad are to blame, as this teaches their children many different ways of running a business. However, the way in which the younger generations set up their businesses reveals that guanxi (relationships and networking) and sinyong (trust) still matter but with a different content. Most partnerships are with other Chinese Indonesians, often referred to as friends they know from school or their church. So although the wish to express their ethnic identity as ethnic Chinese is said not to matter for the younger generation Chinese Indonesians, it does seem to matter in their business practices.

Although Chineseness, as argued by Heryanto, obviously is not a "thing", under certain circumstances it might get "frozen in time" and the case under scrutiny here is an explicit example thereof. ${ }^{61}$ The discursive and generational enquiry shows that the older generation aims to revive Chineseness, or the content of Chineseness, from the times before it was erased and silenced down by state policies in the 1960s. Their

\footnotetext{
${ }^{61}$ Ariel Heryanto, "Ethnic Identities and Erasure. Chinese Indonesians in Public Culture," in Joel Kahn, ed., Southeast Asian Identities. Culture and the Politics of Representation in Indonesia, Malaysia, Singapore, and Thailand (London: I.B. Tauris Publishers, 1998), 95-114.

型 Springer
} 
discourse returns explicitly to those times and relates how both Chinese manners and business practices were put to a halt under a regime in which they could no longer employ (at least in the open) their cultural values and norms. As a result, their children have become 'victims' of the assimilation policies. Obviously, at home these Chinese norms and values were still part and parcel of family life; but they were certainly not part of the public spheres in which their children acted out in daily life. This helps to explain why the voices of the younger generation offer a more mixed message: they state to be and feel Indonesian, but in business matters and in certain personal matters (marriage) they juxtapose themselves with Indonesians. The frozen state of Chineseness is being 'confronted' by the younger generations in that new layers of content are added.

Hence, older and younger generations of Chinese Indonesian entrepreneurs active in small and medium sized companies still very much rely on personal networks that are intra-ethnically based. However, it is not argued that this is the only way they do business; what has been shown is that it is, under the circumstances of an oppressive system, very much the preferred way. Factors explaining this outcome can be found in the ethnic policies of the Indonesian nation state but also in a firm belief among the Chinese Indonesian entrepreneurs across generations in this specific location (Yogyakarta, Java) that a common ground, business-wise, is best found among other Chinese Indonesian entrepreneurs. The business practices as such show an interesting mixture of 'cultural values' and 'best practices business- wise'; in fact a merging of the cultural and critical perspectives. It is important to stress that it is too soon to do away with the cultural layers as such; by paying proper attention to socio-economic and sociopolitical contexts a more nuanced picture emerges and in some cases cultural-ethnic values (whether 'true' or a 'myth') still matter. As Ooi shows in the opening article of this volume, such packaging and unpacking of culture as 'practiced' by researchers but also by those studied, should be constantly on our minds.

This case of Chinese Indonesian entrepreneurs in Yogyakarta show that the status $q u o$ in the debate between the 'culturalists' and 'criticalists' is in need of new questions and methods; and that such new insights can be obtained by giving voice to those concerned and by incorporating a generational perspective.

Acknowledgements The author expresses her gratitude to Arieke Oostra who was willing to conduct her MA research in the context of my research programme, to Andreas Susanto for introducing me into the Chinese community in Yogyakarta and for his willingness to join me in several interviews, to Irwan Abdullah for providing me hospitality at the Centre for Religious and Cross-cultural Studies at the Gadja Mada University Yogyakarta during my field work, and to the two anonymous reviewers for their insightful comments on an earlier draft. Any errors or omissions are the responsibility of the author alone.

\section{Appendix}

Table 1 Chinese Indonesian SME's

\begin{tabular}{llll}
\hline Name/gender & Born & Kind of enterprise & SME \\
\hline Sri (f) & 1935 & Sanitary equipment sales & Small \\
Benni (m) & 1944 & Cement distributor \& drugstore & Medium \\
& & & $\underline{\underline{2} \text { S Springer }}$
\end{tabular}


Table 1 (continued)

\begin{tabular}{llll}
\hline Name/gender & Born & Kind of enterprise & SME \\
\hline Brenda (f) & 1945 & Hand-made tile factory & Medium \\
Harri (m) & 1948 & Computer (sales and repair) & Medium \\
Ronald (m) & 1948 & Water Installation \& Bookstore & Medium \\
Otto (m) & 1949 & Juices \& Kecap production & Medium \\
Go (m) & 1949 & Printing \& publishing & Large \\
Herman (m) & 1949 & Printing business & Small \\
Alief (m) & 1950 & Interior design store & Small \\
Danny (m) & 1950 & Distributor of eggs & Small \\
Yunas (m) & 1953 & Care \& motorcycle parts sales & Small \\
Heriyanto (m) & 1954 & Sales & Small \\
Barnard (m) & 1959 & Car repair shop & Small \\
Boedi (m) & 1959 & Self-employed & Small \\
Daniel (m) & 1960 & Consultancy & Small \\
Siti (f) & 1961 & Silver sales and design & Medium \\
Aris (m) & 1964 & Contractor & Small \\
David (m) & Sanitary sales & Small \\
Samsul (m) & 1965 & Multilevel marketing & Medium \\
Agus (m) & 1965 & Multilevel marketing & Small \\
Rina (f) & 1971 & Household utensils distributor & Small \\
Oskar (m) & 1974 & Car repair floor & Small \\
Budi (m) & 1979 & Mobile phone and repair shop & Small \\
\hline & 1981 & O & \\
\hline
\end{tabular}

Source: fieldwork Yogyakarta 2004 (Koning \& Oostra)

Juliette Koning is senior lecturer in the Department of Culture, Organization and Management at the VU University Amsterdam and coordinator of the Southeast Asia programme of the Faculty of Social Sciences. She holds a PhD in social anthropology from the University of Amsterdam (1997) on ruralurban youth migration in Indonesia. Her main research interests focus on gender and identity questions in Southeast Asia, and religion, enterprise culture and ethnic entrepreneurship in Indonesia. Books and edited volumes include Women and Households in Indonesia, Cultural Notions and Social Practices (2000), Natural Resources and Social Security (2001), Generations of Change (2004) and Rope Walking and Safety Nets: Local Ways of Managing Insecurity in Indonesia (2006). 